UDC 663.813

DOI: $10.15587 / 2706-5448.2021 .242180$

Article type «Reports on Research Projects»

\title{
Natalia Stetsenko, Iryna Goyko \\ DEVELOPMENT OF A METHOD FOR PRODUCING A HEALTHY DRINK BASED ON FERMENTED BEET JUICE
}

The object of research is a method of producing a fermented drink from natural raw materials, the consumption of which will provide the human body with probiotics, prebiotics, vitamins and antioxidants. The work used general scientific research methods, in particular, analysis and synthesis, as well as physicochemical methods for determining the composition and properties of raw materials and the finished product. Beetroot and its juice are insufficiently used in the food and processing industries, therefore this particular type of raw material has great reserves and prospects for creating health products. The work is aimed at improving the method of obtaining fermented beet juice enriched with ginger extract. For the production of the drink, the root crops of the Cylindra variety were chosen, which had a high content of dry substances and sugars, and were also characterized by a better storage capacity with minimal losses of biologically active substances. It has been established that when obtaining juice, it is advisable to process crushed pectolytic beets with the enzyme preparation Fructocyme MA-X-Press (manufacturer Russia). This makes it possible to increase the juice yield by $14.9 \%$, the amount of dry matter by $2.1 \%$ and the sugar content by $1.7 \%$. To ferment the juice used bacterial preparations of lacto- and bifidobacteria in the amount of $5 \%$ by weight of raw materials. The fermentation was carried out at a temperature of $37^{\circ} \mathrm{C}$ for 24 hours. It was found that when using the preparation of B. longum bifidobacteria, which have good stability in an acidic medium, a higher fermentation rate is achieved. To enrich the drink with substances with antioxidant properties, ginger root extract was used. The health-improving effect of the fermented drink is due to the use of exclusively natural plant materials and the use of probiotic cultures of microorganisms in the technological process, which improve the functioning of the gastrointestinal tract and are factors that stimulate the immune system.

Keywords: beetroot, beet juice, fermented juice, ginger extract, health drink.

Stetsenko, N., Goyko, I. (2021). Development of a method for producing a healthy drink based on fermented beet juice. Technology Audit and Production Reserves, 5 (3 (61)), 33-35. doi: http://doi.org/10.15587/2706-5448.2021.242180

\section{Introduction}

Analysis of the actual nutritional status of the population, modern advances in nutritional science, the development of biochemistry and physiology of nutrition, pharmacological nutritiology have led to the emergence in industrially developed countries of the direction of creating functional food products, the production of which is constantly growing. Such products should exhibit a systemic physiological effect, contribute to the restoration of disturbed functions of organs and body systems, and also have optimal metabolic effects. For example, for Ukraine, the task of revising and improving therapeutic and preventive nutrition, creating a healthy food industry and expanding the range of functional and health-improving food products is extremely relevant and requires a solution.

An important task is the development of new technologies for processing vegetables into high quality products, which ensure the prevention of alimentary-dependent conditions and diseases, contribute to the elimination of the deficiency of vitamins, macro-, microelements and other essential substances.
According to the Ministry of Agrarian Policy and Food of Ukraine, no more than $15 \%$ of the total resource potential of vegetable crops is used for industrial processing [1]. Fermented vegetable juices are promising products of therapeutic and prophylactic nutrition, for the production of which juices from cabbage, carrots, potatoes, Jerusalem artichoke and celery are most often used [2, 3]. It is possible to expand the range of such products by processing beetroot into juice, which will be fermented by probiotic microorganisms. So, the object of the study is a method of producing a fermented drink based on beet juice, the consumption of which will provide the human body with probiotics, prebiotics, vitamins and antioxidants.

Beet juice is characterized by a high content of vitamins B1, B2, B12, P, C, carotenoids, folic acid, iodine, zinc, iron, manganese, copper. The last three elements have a positive effect on the processes of hematopoiesis and metabolism, on the functions of the gonads. Zinc has a powerful immunomodulatory ability, supports the action of insulin, increases visual acuity, the body actively needs it in case of myocardial infarction $[4,5]$. Red juice pigments (betacyanins) 
and betaine have antioxidant activity, increase immunity and are recommended for the prevention of cancer [6].

Consumption of fermented vegetable juices prevents malignant cell transformation [5, 7]. This effect can be enhanced by the addition of herbal extracts. Therefore, the aim of this research is to improve the method for obtaining fermented beet juice enriched with ginger extract.

\section{Methods of research}

Vegetable raw materials were evaluated and examined in accordance with the requirements of DSTU 7033:2009. Fresh table beets. Technical conditions. When analyzing beet root vegetables, the quality requirements specified in the UNECE FFV-59 standard concerning the marketing and commercial quality control of root and tuberous vegetables (2017) were taken into account. The work used general scientific research methods, in particular, analysis and synthesis, as well as physicochemical methods for determining the composition and properties of raw materials and finished products [8]. In particular, the content of dry substances was determined refractometrically, the total sugar content was determined by the Bertrand method, active acidity was determined by the potentiometric method, the content of substances with antioxidant properties was determined spectrophotometrically, and the content of ascorbic acid was determined by the photometric method. The magnitude of the error in the conducted studies did not exceed $4.5 \%$ with the number of parallel determinations from 3 to 5 , the probability $P \geq 0.95$.

\section{Research results and discussion}

An assessment was made of the quality of beet root crops of different varieties. The results of determining their biochemical composition and physicochemical parameters are presented in Table 1.

It has been established that beet roots of all varieties accumulate a significant amount of dry matter, of which almost half is represented by sugars. The maximum content of sugars, ascorbic acid and bioflavonoids is observed in Cylindra table beets. The authors of the study [9] found that the root crops of this particular variety are characterized by the minimum losses of biologically active substances during storage and the highest keeping quality, therefore, in this work, for processing, let's used the roots of table beets of the Cylindra variety.

Indicators of the quality of table beets of different varieties

Table 1

\begin{tabular}{|l|c|c|c|}
\hline \multirow{2}{*}{\multicolumn{1}{|c|}{ Indicator }} & \multicolumn{3}{c|}{ Variety } \\
\cline { 2 - 4 } & Cylindra & Nosovsky & Bordeaux \\
\hline Dry matter, \% & $17.3 \pm 0.04$ & $17.6 \pm 0.05$ & $17.2 \pm 0.042$ \\
\hline Acidity, \% & $0.15 \pm 0.006$ & $0.14 \pm 0.004$ & $0.10 \pm 0.002$ \\
\hline Sugar content, \% & $8.5 \pm 0.02$ & $6.8 \pm 0.01$ & $8.3 \pm 0.03$ \\
\hline Ascorbic acid content, mg & $12.7 \pm 0.008$ & $11.4 \pm 0.005$ & $10.3 \pm 0.003$ \\
\hline Bioflavonoid content, mg & $185 \pm 0.14$ & $172 \pm 0.09$ & $179 \pm 0.12$ \\
\hline
\end{tabular}

At the next stage of the research, the dependence of the quantitative yield of table beet juice and its quality indicators on the method of pretreatment of root crops was determined. The research subjects were fresh, frozen, and thermally processed vegetables. It was found that blanching and freezing increased the juice yield by 5.3 and $6.1 \%$, respectively. The maximum yield of dry substances was observed when fresh beets were used, therefore, in order to reduce the duration of the technological process and save energy resources, it was decided that it was not advisable to carry out preliminary heat treatment or freezing of beets.

In work [10] it was found that when obtaining juices without pulp, both illuminated and unlit, pectolytic enzyme preparations are widely used, catalyzing the cleavage of glycosidic and ester bonds in the pectin molecule. Therefore, the effect of the enzyme preparation Fructocyme MA-X-Press (manufacturer Russia) on the juice yield and its composition was investigated (Table 2).

The resulting juice was subjected to a fermentation process, which is based on the use of certain strains of pure cultures of microorganisms. Starter cultures of bacterial preparations of lactobacilli (L. plantarum) and bifidobacteria $(B$. longum) were preliminarily activated in skim milk. Sourdough consumption was $5 \%$ by weight of the processed raw material. The fermentation was carried out at a temperature of $37{ }^{\circ} \mathrm{C}$ for 24 hours. The dynamics of fermentation was assessed by the increasing titratable acidity, which was expressed in mass percent, as well as by the change in active acidity (Table 3 ).

Table 2

Physicochemical indicators of beet juice when processing crushed root crops with an enzyme preparation

\begin{tabular}{|c|c|c|c|}
\hline $\begin{array}{c}\text { Duration of pro- } \\
\text { cessing, min. }\end{array}$ & Juice yield, \% & Solids content, \% & Sugar content, \% \\
\hline control & $42.3 \pm 0.80$ & $13.9 \pm 0.03$ & $8.5 \pm 0.02$ \\
\hline 30 & $45.5 \pm 0.66$ & $14.4 \pm 0.04$ & $9.1 \pm 0.02$ \\
\hline 60 & $48.3 \pm 0.54$ & $15.0 \pm 0.03$ & $9.6 \pm 0.02$ \\
\hline 90 & $52.7 \pm 0.68$ & $15.8 \pm 0.03$ & $10.0 \pm 0.03$ \\
\hline 120 & $57.2 \pm 0.74$ & $16.0 \pm 0.02$ & $10.2 \pm 0.02$ \\
\hline
\end{tabular}

Table 3

Change in active and titratable acidity when fermenting beet juice

\begin{tabular}{|c|c|c|c|c|}
\hline \multirow{2}{*}{ Time, h } & \multicolumn{2}{|c|}{ Active acidity, $\mathrm{pH}$ units } & \multicolumn{2}{c|}{ Titratable acidity, \% } \\
\cline { 2 - 5 } & L. plantarum & B. longum & L. plantarum & B. longum \\
\hline 0 & $6.22 \pm 0.02$ & $6.22 \pm 0.02$ & $0.26 \pm 0.004$ & $0.26 \pm 0.004$ \\
\hline 4 & $5.97 \pm 0.03$ & $5.99 \pm 0.02$ & $0.29 \pm 0.002$ & $0.31 \pm 0.001$ \\
\hline 8 & $5.49 \pm 0.02$ & $5.53 \pm 0.06$ & $0.35 \pm 0.005$ & $0.37 \pm 0.001$ \\
\hline 12 & $5.02 \pm 0.02$ & $5.08 \pm 0.03$ & $0.41 \pm 0.004$ & $0.49 \pm 0.002$ \\
\hline 16 & $4.92 \pm 0.01$ & $4.70 \pm 0.04$ & $0.45 \pm 0.003$ & $0.56 \pm 0.005$ \\
\hline 20 & $4.78 \pm 0.04$ & $4.55 \pm 0.04$ & $0.49 \pm 0.003$ & $0.66 \pm 0.004$ \\
\hline 24 & $4.66 \pm 0.05$ & $4.48 \pm 0.02$ & $0.51 \pm 0.004$ & $0.71 \pm 0.006$ \\
\hline
\end{tabular}

It was found that at the first stage of fermentation, the process was more active when using $L$. plantarum lactobacilli, but after 8 hours the fermentation rate increased in the sample treated with $B$. longum bifidobacteria. The choice of this starter culture is advisable, since it is due to the high rate of fermentation, the stability of $B$. longum in an acidic environment, and a good ability to take root in the human gastrointestinal tract [11].

To improve the organoleptic properties and health effects of fermented beetroot juice, it is proposed to add ginger extract. It contains essential amino acids: threonine, tryptophan, lysine, phenylalanine, methionine and valine. Among the micro- and macroelements available are $\mathrm{K}, \mathrm{Ca}, \mathrm{Fe}, \mathrm{Mg}$, $\mathrm{F}, \mathrm{K}, \mathrm{Na}, \mathrm{Zn}, \mathrm{Cu}, \mathrm{Mn}$. Ginger root is a source of vitamins such as C, B2, A, E. Ginger has antimicrobial, antifungal, 
antitoxic, sedative, anti-inflammatory properties, improves blood circulation, stomach function, increases blood pressure.

The most convenient and rational way to obtain natural antioxidants from plant materials is extraction. It was determined that the optimal degree of grinding of ginger rhizomes for this process is $5-6 \mathrm{~mm}$, and the ratio of raw materials: extractant is $1: 10$. These parameters ensured the content of phenolic compounds in the extract in the amount of $132.6 \mathrm{mg}$ and ascorbic acid $4.95 \mathrm{mg}$. At a dosage of the extract in an amount of $6 \%$ by weight of fermented beet juice, the drink had a harmonious taste and aroma, which were improved by the use of ginger extract.

Blending of fermented beet juice and ginger root extract was carried out in a cold way. The resulting fermented juice was sent to deaeration, which, together with subsequent heat treatment, prevented undesirable oxidation processes of the finished product. Before bottling, the fermented blended juice was cooled to a temperature of $4 \pm 2{ }^{\circ} \mathrm{C}$. Physicochemical parameters of the developed drink are presented in Table 4.

Table 4

Physicochemical characteristics of a drink made from fermented beet juice enriched with ginger extract

\begin{tabular}{|l|c|}
\hline \multicolumn{1}{|c|}{ Indicator } & Value \\
\hline Mass fraction of dry substances, \% & $12.3 \pm 0.04$ \\
\hline Sugar content, \% & $9.2 \pm 0.01$ \\
\hline $\mathrm{pH}$ & $4.55 \pm 0.02$ \\
\hline Total content of phenolic compounds, mg & $162.4 \pm 0.16$ \\
\hline Ascorbic acid content, mg & $7.3 \pm 0.006$ \\
\hline
\end{tabular}

It is important to note that in order to ensure good organoleptic properties of a drink from fermented beet juice, it is necessary to use for processing those varieties of table beets, which are characterized by a high content of dry substances, including sugars. In addition, root crops should show keeping quality without losing biologically active substances during their storage, therefore it is advisable to use Cylindra table beets. In the process of fermenting the resulting juice with preparations of bifidobacteria, it is necessary to strictly observe the temperature regime of $37 \pm 2{ }^{\circ} \mathrm{C}$.

The limitations of this study are that the biochemical composition of plant materials depends on the climatic conditions of growing, the timing of its collection and storage. Therefore, the physicochemical properties of beet juice and a drink created from it may differ to a certain extent from the values presented in this work.

A promising direction in the development of the research is expanding the range of beverages from fermented beet juice, as well as increasing their biological value by adding extracts of various spicy-aromatic and medicinal plant raw materials. This will provide a targeted physiological effect and a positive effect on the functioning of organs and systems of the human body.

\section{Conclusions}

In the course of the research, it was found that for the production of a health-improving fermented drink, it is advisable to use Cylindra beetroot. Before withdrawing the juice, the crushed raw materials must be treated with the enzyme preparation Fructocyme MA-X-Press. This makes it possible to increase the juice yield by almost $15 \%$, the dry matter content by $2.1 \%$, and the total sugar content by $1.7 \%$.
It is shown that for the fermentation of the obtained juice, the starter culture of bifidobacteria $B$. longum should be used in an amount of $5 \%$ to the mass of raw materials at a temperature of $37{ }^{\circ} \mathrm{C}$ for 24 hours. It was found that the addition of $6 \%$ ginger extract to the fermented beet juice provides high organoleptic properties of the resulting drink and its antioxidant effect due to the content of phenolic compounds $162.4 \mathrm{mg}$, as well as ascorbic acid $7.3 \mathrm{mg}$.

Expanding the range of food products obtained by processing beetroot will make it possible to more fully use the natural potential of the beneficial ingredients of this root crop. The health-improving effect of the drink from fermented beetroot juice and ginger extract is due not only to the use of exclusively natural plant materials, but also to the use of bifidobacteria, which provide the probiotic properties of the finished product. The presence of a significant amount of betalains, phenolic compounds and ascorbic acid determines the antioxidant properties of the finished product.

\section{References}

1. Zhuzhukina, N. I. (2015). Osoblyvosti biznes-diyalnosti promyslovoi pererobky ovochiv ta fruktiv. Prodovolchi resursy. Seriya: Ekonomichni nauky, 4, 79-83.

2. Filipova, L. Yu., Rakulenko, N. A. (2012). Naukove obgruntuvannia ta vybir perspektyvnykh napriamiv pereroblennia ovochevykh ta bashtannykh kultur. Naukovi pratsi ONAKhT, 42 (2), 59-64.

3. Kohajdová, Z., Karovičová, J., Greifová, M. (2006). Lactic acid fermentation of some vegetable juices. Journal of Food and Nutrition Research, 45 (3), 115-119.

4. Wruss, J., Waldenberger, G., Huemer, S., Uygun, P., Lanzerstorfer, P., Müller, U. et. al. (2015). Compositional characteristics of commercial beetroot products and beetroot juice prepared from seven beetroot varieties grown in Upper Austria. Journal of Food Composition and Analysis, 42, 46-55. doi: https://doi.org/ 10.1016/j.jfca.2015.03.005

5. Hoffman, D. J. (2020). Use of Beetroot Juice Extract for Hypertension Treatment in Low- and Middle-Income Countries. The Journal of Nutrition, 150 (9), 2233-2234. doi: https://doi.org/ $10.1093 /$ jn/nxaa215

6. Kayın, N., Atalay, D., Türken Akçay, T., Erge, H. S. (2019). Color stability and change in bioactive compounds of red beet juice concentrate stored at different temperatures. Journal of Food Science and Technology, 56 (11), 5097-5106. doi: https:// doi.org/10.1007/s13197-019-03982-5

7. Yoon, K. Y., Woodams, E. E., Hang, Y. D. (2005). Fermentation of beet juice by beneficial lactic acid bacteria. LWT - Food Science and Technology, 38 (1), 73-75. doi: https://doi.org/ 10.1016/j.lwt.2004.04.008

8. Skaletska, L. F., Podpriatov, H. I., Zavadska, O. V. (2013). Metody doslidzhen roslynnytskoi syrovyny. Kyiv: TsP «Komprynt», 242.

9. Skaletska, L. F., Zavadska, O. V., Iliuk, N. A. (2015). Pidbir koreneplodiv buriaka stolovoho riznykh sortiv dlia pererobky. Naukovyi visnyk Natsionalnoho universytetu bioresursiv i pryrodokorystuvannia Ukrainy: Seriia: Ahronomiya, 210 (1), 261-265.

10. Klewicka, E., Zduńczyk, Z., Juśkiewicz, J. (2009). Effect of lactobacillus fermented beetroot juice on composition and activity of cecal microflora of rats. European Food Research and Technology, 229 (1), 153-157. doi: https://doi.org/10.1007/s00217-009-1036-х

11. Gawkowski, D., Chikindas, M. L. (2013). Non-dairy probiotic beverages: the next step into human health. Beneficial Microbes, 4 (2), 127-142. doi: https://doi.org/10.3920/bm2012.0030

$\triangle$ Natalia Stetsenko, PhD, Associate Professor, Department of Health Food Technology, National University of Food Technologies, Kyiv, Ukraine, e-mail: stetsenkono_nuft@ukr.net, ORCID: https:// orcid.org/0000-0001-6710-024X

Iryna Goyko, PhD, Associate Professor, Department of Health Food Technology, National University of Food Technologies, Kyiv, Ukraine, ORCID: https://orcid.org/0000-0002-1680-5087

$\triangle$ Corresponding author 